\title{
Factors Determining Effectiveness of Internal Audit in Commercial Banks: The Case of Study (Commercial Banks of Herat-Afghanistan)
}

\author{
Marouf FAQIRI ${ }^{1}$ \\ Esin Nesrin CAN ${ }^{2}$
}

\begin{abstract}
Internal audit plays a major role in enabling an institution to achieve its goals when properly implemented, operated, and managed. To take corrective measures and strengthen procedures, companies that implemented, operated and managed internal auditing successfully became more able to recognize their business threats and inefficiencies in the system. The overall goal of the paper is to recognize factors influencing the effectiveness of internal audit in commercial banks of Herat-Afghanistan. At the moment, 13 banks are operating in Afghanistan including DAB (Central Bank of Afghanistan) DAB (2020), three state-owned banks (Bank Millie Afghan, Pashtany Bank, New Kabul Bank), seven private or commercial banks (Azizi Bank, Afghanistan International Bank, Islamic Bank of Afghanistan, Maiwand Bank, Afghan United Bank, The First MicroFinance Bank, Ghazanfar Bank) and two branches of foreign banks (Bank Alfalah ltd, National Bank of Pakistan) with the total number of 158 internal auditors. Therefore, internal auditors of Afghanistan commercial banks are the population for this research. 158 questionnaires were allocated to 12 commercial banks for the purpose; the analysis followed a form of research by using quantitative methods of research. The study tool used in quantitative terminology through self-administered questionnaires. These questionnaires were prepared on a 5 point Likertscale, distributed to the Afghanistan Commercial Banks' internal auditors and analyzed using the SPSS statistical software. Based on the research
\end{abstract}

\footnotetext{
${ }^{1}$ Istanbul Aydin University, Department of Business Management (Graduate), m.faqiri@jami.edu.af, 0000-0002-2066-8839.

${ }^{2}$ Dr., Istanbul Aydin University, Department of Business, esincan@aydin.edu.tr, 0000-0002-3525-0793 Doi Num: 10.17932/IAU.FCPE.2015.010/fcpe_v06i1004
} 
results; Management commitment and supports had a positive relationship with the efficacy of the internal audit regarding value-adding, improving departmental performance, and improving organizational efficiency, with clear and statistically significant consequences. In this respect, the only determining factor of the effectiveness of the Internal Audit of commercial banks in Herat-Afghanistan was management support.

Keywords: Internal Audit, Internal Audit Effectiveness, and Afghanistan Commercial Banks.

\section{Ticari Bankalarda İç Denetimin Etkinliğini Belirleyen Faktörler: Araştırma (Herat-Afganistan'ın Ticari Bankaları)}

\section{$\ddot{O Z Z}$}

İç denetim, uygun şekilde uygulandığında ve yönetildiğinde kurumun hedefine ulaşmasını sağlamada önemli rol oynar. Düzeltici önlemler almak ve prosedürleri etkinleştirmek amacıyla iç denetim uygulayan kurumlar, iş tehditlerini ve sistem verimsizliklerini daha iyi belirleyebilir. Bu çalışmanın amac1, Herat-Afganistan'daki ticari bankalarda iç denetim etkinliğini belirleyen faktörleri ortaya koymaktadır. Çalışmada, "amaçlı örnekleme" yaklaşımı kullanılmış olup Afganistan Ticari Bankalar genel merkezi iç denetçilerini kapsamaktadır. Analiz, nicel araştırma yöntemleri kullanılarak yapılmıştır. Çalışmada araç olarak nicel araştırma terminolojisinde yer alan "anket yöntemi” uygulanmıştır. Afganistan Ticaret Bankası'nın iç denetçilerinden 147'si tarafindan doldurulan bu anketlerde 5'li Likert ölçeği kullanılmış ve SPSS istatistik yazılımı kullanılarak sonuçlar analiz edilmiştir. Araştırma sonuçlarına göre; katma değer yaratma, departman performansını iyileştirme ve örgütsel verimliliği artırma konularında yönetim desteğinin, iç denetimin etkinliği üzerinde açı ve istatistiksel olarak anlamlı sonuçlarla olumlu bir etkisinin olduğu tespit edilmiştir. Bu bağlamda, Herat Afganistan'daki ticari bankaların iç denetiminin etkinliğini belirleyen tek faktör yönetim desteğidir. Araştırmacının ana önerisi; üst yönetimin iç denetim personelini desteklemesi iç denetim departmanının genişletilmesi ve iç denetim ekibinin gereksinmelerinin karşılanmasıdır.

Anahtar Kelimeler: İç Denetim, Afganistan Ticari Bankaları ve İç Denetimin Etkinliği. 


\section{INTRODUCTION}

With the division of ownership and management between businesses that are supposed to lead to interest tensions between agents and administrators, the importance of auditing has increased in the modern economy Adams (1994). The development of disciplined corporate firm governance is one of the most effective ways of controlling and fostering corporate worthy governance structures Belay (2007). Internal assessment is an integral aspect of the system of business management within a company and involves auditor tasks performed for boosting financial statements accuracy system by the board of directors and audit committee. The popularity of internal audit expanded due to the organizational crisis that began at the close to the end of the $20^{\text {th }}$ century.

William, Brierley and Al-Twaijry, (2003 state that it has two benefits to have an $\mathrm{IAD}^{3}$ for organizations. First of all, it improves the everyday activities of companies and control risk. Second, it allows a company to avoid and track mistakes and fraud to protect assets. In different laws such as the Moeller (2004) and the Corporate Governance Principle of OECD 4 the significance of IA $^{5}$ was confirmed. Developing world organizations may not identify the usage and value of IA as demonstrated by studies carried out in Libya, Tanzania, Kenya, and Ethiopia.

Researchers nowadays have more emphasis on the role of the organization's IA and internal auditor than ever before Changwony and Rotich, (2015); George, (2015); Ibrahim M. S., Shokiyah, A., and Baharud-din (2014). Meanwhile, greater attention has been paid to matters like performance assessment, and IA efficiency. IAF ${ }^{6}$ in a constantly changing economic, and business climate takes into account operational dynamics and focuses on an advisory approach to the performance of an enterprise, and productivity rather than tracking accuracy Willborn and Karapetrovic (2000). IA has shifted from an accounting quality appraisal program to a value-adding feature Rupsys and Staciokas (2005). The value-adding role allows the business to obtain economy, efficiency, productivity as well as good performance. Although, different

\footnotetext{
${ }^{3}$ Internal Audit Department

${ }^{4}$ Organization for Economic Cooperation and Development

${ }^{5}$ Internal Audit

${ }^{6}$ Internal Audit Functions
} 
investigators say IAF is not always successful Ramachandran, et al., (2012); Wubishet and Dereje (2014). Auditing works have historically been carried out and viewed according to the empirical dimension of agency theory Hanefah and Endaya (2013); Gilchrist, D. Pilcher, R. and Singh (2011). As a result, some of the researchers suggested using institutional theory AbuAzza (2012); Mihret (2008). The research investigated to incorporate and analyze the study conclusions from a different perspective relying on the theoretical basis of Hanefah and Endaya (2013) to assess the efficacy of IA as opposed to previous studies. The combination of three theories is another approach adopted by Endaya and Hanefa (2013), institutional, agency and communication. Though agency theory is specifically used in this analysis to know the scientific passion that finds the internal auditors aim, while they are against the wishes of the members of the administrational agendas, to pursue their goals. The synthesis of three hypotheses is a new path adopted by Hanefah and Endaya (2013). The theory of communication describes the importance of efficient contact with business internal and external auditors.

\section{Objectives of the Study}

- Examining of the internal auditor's competence to ensure that internal auditing is successful in $\mathrm{ACBs}^{7}$.

- Analyzing, the level of the independence of the inner auditor in the performance of internal audit in ACBs.

- Measuring the degree to which the internal audit quality of ACBs is successful.

- To investigate the extent of IA operation under adequate management support in ACBs.

\section{Research Hypotheses}

$\mathbf{H}_{\mathbf{1}}$ : The competence of the IA department is directly related to the IA effectiveness in ACBs.

$\mathbf{H}_{2}$ : The IA efficiency in Afghanistan Commercial Banks is strongly connected to IA's independence.

$\mathbf{H}_{3}$ : IA work quality is well correlated with IA efficiency in Afghanistan Commercial Banks.

$\mathbf{H}_{4}$ : The effectiveness of the IA in ACBs is positively related to management support. 


\section{LITERATURE REVIEW}

A detailed description of auditing is as follows:

Auditing is the collection and review of information details to assess the degree of correlation between the data and the standards defined and the report. Arens (2012). Arens notes that audit can be divided into two, depending on the main beneficiary for the audit: External Audit and Internal Audit. Auditors acting in such a way that audits are known respectively as internal and external auditors.

As per Arens, external auditors are not staff of the audited entity and send a financial report to ensure that the report gives a real, and accurate representation of the firm's financial health description. Internal auditing from the other side seems to be an independent and objective assessment with a great balance of monitoring and advisory activity of business operations, usually by their staff, although seldom by outside experts in risk management, supervision, consulting and governance. Domestic auditors have the opportunity to easily obtain data, rapidly identify issues and provide a report on problems Xiangdong (1997). As a consequence, IA has an additional benefit over the external audit. Although, in comparison with external audit, inadequate attention has been paid to internal audit in prior studies William, et, al. (2003), Yismaw, A.W., and Mihret, D.G., (2007).

\section{Internal Audit in Commercial Banking Sector}

As a result of the companies' collapse that started around the later part of the 20th century, IA importance increased Moeller (2004). In the commercial banking sector, the financial disaster was also similar. A total absence of effectiveness in its review function was the primary reason for a CBs inability in different areas of the world (e.g. Kenya and Nigeria). As a result, the experiences of such a disaster in these countries called for the development and strength of IA Changwony, M. K., and Rotich, D. G., (2015). This is critical since active $\mathrm{IAD}^{8}$ is necessary for the success of powerful CBs. Commercial Banking offers various types of services by holding large sum amount of funds for clients Tandon, B., Sudharsanam, S., and Sundharabahu, S. (2010). In this respect, it is the lifeblood of the national economy Keatinge, T., (2014). Because of this evidence,

${ }^{8}$ Internal Audit Department 
it is not necessary to compromise IA in CBs; the efficiency of IA in the safe and sound financial system of CBs would be positive Fernando, A., Lock, K. L., and Gamage, C. (2014). This will assist CBs in protecting their resources, producing accurate financial records and following the legislation Fernando, A., Lock, K. L., and Gamage, C., (2014). Thus, it improves IAD and the organizations overall performance Tandon, B., Sudharsanam, S., and Sundharabahu, S., (2010).

Xiangdong (1997) explained the role of IA over an economy through agency theory. Similarly, in respect of agency theory, Fadzil, F. H., Haron, H., and Jantan, M. (2005) talked about binding costs paid to internal auditors for the achievement of organizational interests.

\section{The Internal Auditing Standard}

Domestic audit is one of the bank's main units, the internal revenue board is aware that the income amount on which tax is not manipulated, according to Nagy, A. and Cenker, W., (2002) and that at the end; the accountant reports approves steps for better and effective future performance. Internal audit investigates and measures the overall accuracy of the domestic control process, its suitability, and its efficiency. Nagy, A., and Cenker, W., (2002) "external audit detects and avoids mistakes, frauds, and results based on economic records honesty and fairness".

Financial institutions like to create a powerful interior auditing structure since that makes analyzing and evaluating the bank's actual performance the easiest and best way for the panel of the director. Basel internal auditing criteria are most recommended for understanding and strengthening bank audit performance. It is best to conform to the system defined in the United States in 2018 by IIA 9 . All the operations of the bank should be protected by the IA, to obtain the expected benefits of the auditing pointed to above. Professional and unbiased internal auditing teams are very essential as audits can be used to track the general operation of the firm by the top management board. In 2012 the Basel Banking Supervisory Committee provided the internal audit position in banks.

\footnotetext{
${ }^{9}$ Institute of Internal Audit
} 


\section{Conceptual Framework}

Based on Abu-Azza (2012), Hanefah, M. M., and Endaya, K. A., (2013), and George (2015) studies on IA; in determining IA effectiveness, the researcher attempts to try the following conceptual framework:

Figure 1: Conceptual Model for Effectiveness of Internal Audit in $\mathrm{ACBs}^{10}$

\begin{tabular}{|c|c|c|c|c|}
\hline \multirow{2}{*}{$\begin{array}{l}\text { I. Internal Auditors Competence } \\
\text { A. Proficiency of Internal } \\
\text { B. Improve t } \\
\text { C. Improve C } \\
\text { Auditors } \\
\text { B. Experience of Internal } \\
\text { Auditors } \\
\text { C. Effective Communication } \\
\text { with Auditee } \\
\text { D. Training and Development } \\
\text { E. Access to IT }\end{array}$} & \multicolumn{3}{|c|}{$\begin{array}{l}\text { ess of Internal Audit } \\
\text { ng Role } \\
\text { Department's Performance } \\
\text { ganizational Performance }\end{array}$} & \\
\hline & $\mathbf{H}_{1}$ & & \multicolumn{2}{|c|}{$\begin{array}{l}\text { III. Internal Auditors Quality } \\
\text { A. Effective Audit Planning } \\
\text { and Supervision } \\
\text { B. Internal Audit Field Work } \\
\text { C. Reporting, Finding and } \\
\text { Recommendations } \\
\text { D. Follow-Up of IA } \\
\text { Recommendations } \\
\text { E. Effective Communication } \\
\text { with External Auditors }\end{array}$} \\
\hline $\begin{array}{l}\text { II. Internal Auditors Independence } \\
\text { A. Existence of Effective Audit } \\
\text { Committee } \\
\text { B. Individual Internal Auditors } \\
\text { Independence } \\
\text { C. Organizational Independence } \\
\text { of the Internal Audit } \\
\text { Function }\end{array}$ & $\mathbf{H}_{2}$ & $\mathbf{H}_{4}$ & \multicolumn{2}{|c|}{$\begin{array}{l}\text { IV. Management Support } \\
\text { A. Senior Management } \\
\text { Support } \\
\text { B. Size of Internal Audit } \\
\text { Department } \\
\text { C. Resources of Internal Audit } \\
\text { Team }\end{array}$} \\
\hline
\end{tabular}

Source: Shewhart, W. A. and Wilks, S. S., (2004)

${ }^{10}$ Afghanistan Banks 


\section{RESEARCH METHODOLOGY}

Four theoretical ideologies prevail primarily in science, such as realism, positivism, pragmatism and interpretivism Saunders, et. al. (2009) and Creswell (2009). The four theories in science look different in the world Creswell (2003). Over the past years, scholars have built and extended their knowledge based on the diverse views of the world. For example, the following are the types of philosophy of research they follow. Wubishet and Dereje (2014) positivism (post-positivism), Mihret (2008) constructivism and Abu-Azza (2012) pragmatism. The researcher tried to develop knowledge-based on a pragmatic claim of knowledge in this study. Creswell (2003) defined pragmatism as "a worldview arises out of actions, situations, and consequences rather than antecedent conditions".

Pragmatism is not restricted to a specific form of study; since pragmatists look around the world from different directions and not in absolute terms Creswell (2009). It comprises of quantitative and or qualitative, deductive, inductive, subjective or objective, value biased, therefore, offers the best work through recognizing aspects of analysis hypotheses Saunders, et. al. (2009); the same refers to the compilation and analysis of data.

\section{Population and Sampling}

Most of Afghanistan Banks do not have internal auditors in a local office level. In this analysis, the investigator used the purposive and convenient method of sampling. The purposive sampling method is related to the nature of the research and is prescribed for the nature of the study Mihret (2008).

Even if the variation is not assumed to be strong in the analysis, since the population is not large in number, all banks in the sample frame have been identified by their head office. The total number of the staff of the IADs of the $\mathrm{ABs}^{11}$, is currently numbered around 195 in the head offices; since DAB is the central bank of Afghanistan therefore, the number of population decrease by $195-37=158$.

\section{Research Methods}

This research is conducted through a quantitative study; the quantitative objective of the analysis is to classify the data required for the population to be generalized Marczyk, et al. (2005). Data collection on this survey is

\footnotetext{
${ }^{11}$ Afghanistan Banks
} 
done through a self-administered questionnaire to attain the objective of this research.

\section{Survey Design}

This analysis involves a cross-sectional survey when cross-sectional surveys are used, data cannot be collected at some point as longitudinal overtime but just the data is collected at once Creswell (2009). Forms of surveys include self-administrated questionnaires, interviews, structured record reviews, and organized observations according to Creswell (2009). The researchers used self-administered surveys as useful in this analysis. Many advantages may be like the cheaper option, enable participants to learn more about the problems, which are more confidential and easily gathered data Cooper and Schindler (2006). The survey is, therefore, conducted to decide the factors that determine IA's effectiveness concerning IA team competence, independence, job quality, and management support. There are essentially three ways to handle self-administered questionnaires, including face to face, telephone, and Email Marczyk, et al. (2005). Due to the return rate and intellectual honesty is high in the face to face approach when filling a questionnaire Marczyk, et al. (2005), the investigator used a face to face survey.

\section{Survey Instrument}

George (2015), created the self-administered questionnaire and the investigator used it for this paper. The study is linked to the hypotheses of the research and aims of this study. Nonetheless, the researcher takes up and modifies some questions concerning their contents and explains the claims of the respondents easily. The survey is arranged in two sections. The first section relates to the profiles of the participants. The basic information part contains five questions related to the backstory and current status of the respondent and demographic features. The second section includes twentyone questions of the Likert scale aimed at achievable, homogeneous, and objective analysis of research hypotheses. The second part consisted of groups.

The first group consists of six questions of scale on Likert, which deal with IA team competence; The second group comprises of three questions on Likert scale of IA independence; The third group consists of six questions of Likert scale concerning the quality of IA; The fourth group consists 
of three questions of Likert scale relating to management support; The fifth category comprises three questions of Likert scale which involve IA effectiveness. The language of the questionnaire is Persian and English. Appendix 1 includes a sample of the whole instruments. Mostly, questions on the Likert scale are of five degrees namely strongly agree, agree, neutral (undecided), disagree, and strongly disagree. In the analytics process, these are merged into a single aggregated variable Kothari (2004); Boone $\mathrm{Jr}$ and Boone (2012). Combined elements are used to get a quantitative measure of a personality or character trait Boone and Boone Jr. (2012). A "reasonable" Likert-scale is a scale that is balanced by a neutral choice on both sides, providing a less biased metric. Both the actual scale labels and the numerical scale can vary Vanek (2012). The investigator interpreted Likert scales in five points to show the following values: (1) indicated strongly agree, (2) agree, (3) neutral, (4) disagree and (5) strongly disagree. In the inquiries given, the numbers indicate ordinary scale calculation and the creation of data suitable for quantitative analysis Boone Jr and Boone (2012). In this respect, the mean answer less than 3.00 was considered an acceptance with the questionnaire argument. Whereas, the mean answer above 3.00 is seen as disagree with the questionnaire statement Boone $\mathrm{Jr}$ and Boone (2012). Though, the standard deviation findings of less than 1.00 indicate that the views of the respondent are similar to each other. However, the standard deviation of over 1.00 demonstrated that the perceptions of the participant varied. Shewhart and Wilks (2004).

\section{Data Collection Procedure}

First, the investigator asked a recommendation letter from Istanbul Aydin University, College of Business Administration; Department of Social Science. It is meant to be accepted and to improve participants confidentiality. The questionnaires were then distributed to internal auditors of voluntary ACBs main offices in Herat, Afghanistan. Since the study participants were individual, they maintained their right to participate or not and nothing in addition to ethical considerations were performed without ethical consideration. As Cooper and Schindler (2006) states participants' perceptions subtly influence the results of the research; nobody was obligatory to be involved. 


\section{Data Analysis}

Analysis of the data also includes exploring the main purpose of research, categorizing, tabulating, and recombining data collected Yin (2003). Data analyzed in the quantitative method of analysis. In this paper, the investigator has used the SPSS (Statistical Social Science Package) software to analyze the collected data. The investigator used ordinal sort (ranked) of categorical data based on the chosen survey instrument, which is the basis of the Likert questionnaire. The data collected in this regard was converted using a questionnaire to describe the hypotheses variables. This is by taking mean values for each construct of the item responses. Mean values are selected because the answer to items ranged from "Strongly Agree" to "Strongly Disagree" generate ordinal data Mihret (2008). Using the demographic characteristics and descriptive statistics, mainly frequency count, percentage central tendency calculation (mean), dispersion measurement (standard deviations) have been used to summarize and define the observation results. Moreover, other statistics analyze such as the reliability analysis (Cronbach's Alpha), autocorrelation assessment (Durbin-Watson), regression analysis (ANOVA), and finally hypotheses testing were then presented according to the data collected by questionnaire. The following structure for evaluation of regression was used to assess the effectiveness variables IA.

$\mathrm{EIAiACBs}=\beta_{0}+\beta_{1} \mathrm{COIAt}+\beta_{2} \mathrm{INIA}+\beta_{3} \mathrm{QUIA}+\beta_{4} \mathrm{MGS}+\varepsilon$

EIAiACBs $=$ Effectiveness of Internal Audit in Afghanistan Commercial Banks

$\mathrm{B}_{0}=$ Constant Term

$\mathrm{B}_{1}-\beta_{4}=$ coefficients of independent variables and

COIAt $=$ Competence of IA teams

INIA $=$ Independence of IA

QUIA= Quality of IA Work

MGS=Management Support

$\varepsilon=$ error term 


\section{INTERPRETATION AND DATA RESULTS}

The results of the quantitative data assessment in this section are presented. The hypotheses study is used to assess the major effect of independent variables on the dependent variable Field Survey (2020). Hypotheses are tested in this study for a major influence of IA competency, independence, work quality, and management supports over the effectiveness of IA, which was calculated by adding value to a company, improving departmental performance, and improving corporate efficiency. Table 4 shows that the p-value of management support was statistically significant in terms of management supports $(\mathrm{p}<0.05)$; which suggests excellent support for the fourth hypothesis. Whereas at $(\mathrm{P}<0.05)$, which lacks support for hypotheses 1,2 and 3, the p-value for independence, competence, and quality of IA was statistically insignificant.

\section{Reliability Analysis}

The accuracy of the questionnaire or its reliability is important in a Likertscale questionnaire. In previous IA studies, reliability review was used to adopt the questionnaire throughout the Likert scale Mihret (2008); George (2015); Ababa (2016). The most famous test of the reliability scale is Cronbach's Alpha $(\alpha)$ when evaluating such a reliability study. A value $(\alpha)$ greater than 0.600 in reliability measurement (Cronbach's, 1951) is acceptable. According to the Field survey (2020), a value $(\alpha)$ higher than 0.800 is extremely acceptable for reliability analyzes. Based on Table 1, the Cronbach Alpha $(\alpha)$ reliability measurement value of this study reveals that all variables have 0.876 . The responses produced in this research were therefore extremely acceptable to data analyses (reliable).

Table 1: Reliability Statistics

\begin{tabular}{ccc}
\hline Cronbach's $(\boldsymbol{\alpha})$ & Cronbach's $(\boldsymbol{\alpha})$ Based on Standardized Items & N of Items \\
\hline .876 & .876 & 21 \\
\hline
\end{tabular}

Source: Field Survey, 2020

\section{Autocorrelation Assessment}

As per Brooks (2008) they can be considered as autocorrelated if there are patterns in the residuals from a model. The $\mathrm{DW}^{12}$ is an autocorrelation test of the first order. This assumes the connection of an error to the previous of

\footnotetext{
${ }^{12}$ Durbin-Watson
} 
an error. In such a type of analysis, when the DW result is close to 2 the null hypothesis cannot be rejected Hair, et al. (1998). Because it demonstrates that there is little or no evidence of autocorrelation. There is a positive correlation when it is less than two and when it is more than two there is a negative correlation. The statistical significance of this analysis from DW is 2.161 which is higher than 2 based on Table 2. Therefore, there is negative evidence of autocorrelation among error terms in this survey.

Table 2: D-W Test Model Summaryb

\begin{tabular}{cccccc}
\hline Model & $\mathbf{R}$ & $\begin{array}{c}\mathbf{R} \\
\text { Square }\end{array}$ & $\begin{array}{c}\text { Adjusted } \mathbf{R} \\
\text { Square }\end{array}$ & $\begin{array}{c}\text { Std. Error of the } \\
\text { Estimate }\end{array}$ & Durbin-Watson \\
\hline 1 & $.646^{\mathrm{a}}$ & .417 & .323 & .621 & 2.161 \\
\hline a: IV $^{13}:$ (Constant), Competence of Internal Audit, Independency, Work Quality and \\
Management Support \\
\multicolumn{2}{l}{ b: DV $^{14}:$ Effectiveness of Internal Audit } \\
\hline
\end{tabular}

Source: Field Survey, 2020.

\section{Regression Results (ANOVA) for Internal Audit Effectiveness}

This survey influences on how the participant perceives the questionnaire. So, r-squared can be respectable and good to match, more than 25 percent Reisinger, (1997); Thompson (2002). The regression results investigate the appropriate IA efficiency indicators by using the model variables Hair, et al. (1998). The relevant tests for the variables used to illustrate the efficiency of IA were explored based on Table 2. It means that 41.7 percent $(0.417)$ of the differentiation in the efficiency of internal audit was responsible for the overall contribution of competency of internal audit groups, independence of internal audit, quality of internal audit work and management support. Table 3, ANOVA highlights the importance of the F-statistics $(\mathrm{P}=.000)$ and $\mathrm{F}=21.289$ model, which demonstrates that a strong relationship exists between the forecasts and the effects of the variables of regression. The model is ideally adapted to estimate the efficacy of IA in ACBs.

\footnotetext{
${ }^{13}$ Independent Variable

${ }^{14}$ Dependent Variable
} 
Factors Determining Effectiveness of Internal Audit in Commercial Banks: The Case of Study (Commercial Banks of Herat-Afghanistan)

Table 3: ANOVA $^{\mathrm{a}}$

Source: Field Survey, 2020.

\begin{tabular}{llccccc}
\hline & Model & Sum of Squares & Df & Mean Square & F & Sig. \\
\hline 1 & Regression & 19.321 & 4 & 4.830 & 21.289 & $.000^{\mathrm{b}}$ \\
& Residual & 31.764 & 140 & .227 & & \\
Total & 51.085 & 144 & & & \\
\hline
\end{tabular}

DV: Effectiveness of Internal Audit

IV: (Constant), Independency, Competency, Work Quality and Management Support

\section{Regression Test Results Coefficients}

The beta $(\beta)$ symbol containing a positive $(+)$ or negative $(-)$ sign. It indicates how the IVs influence the DV Field (2020). Table 4 includes a positive $(+)$ beta sign for all independent variables. Therefore, IVs (IA competence, IA independence, IA work quality, and management support) had a positive influence on the forecasting DV (effectiveness of IA). Any improvement in IV contributes to the improvement of the DV. The above outcome is in line with previous IA literature William, et al., (2003); Wubishet and Dereje (2014); Mihret and Yismaw (2007); Ramachandran, et al., (2012); Cohen and Sayag (2010).

The independent variable with a significance level (sig.) of less than 5 percent will make a significant influence on the DV's expected value. Indeed, a variable beyond this significance level (sig.) cannot contribute significantly to the expected value of the DV Hair, et al., (1998); Brooks (2008). Based on table 4, the independent variables' statistical significance over the DV at $5 \%$ of significance; three of the IVs (IA competence, independence and work quality) over the dependent variable (effectiveness of IA) were not significantly contributed. However, for the DV (effectiveness of IA), the IV (management support) had a significant contribution. 
Table 4: Regression Results Coefficients ${ }^{\mathrm{a}}$

\begin{tabular}{lccccccc}
\hline & \multicolumn{2}{c}{$\begin{array}{c}\text { Unstandardized } \\
\text { Coefficients }\end{array}$} & $\begin{array}{c}\text { Standardized } \\
\text { Coefficients }\end{array}$ & \multicolumn{4}{c}{$\begin{array}{c}\text { Collinearity } \\
\text { Statistics }\end{array}$} \\
\hline Model & B & $\begin{array}{c}\text { Std. } \\
\text { Error }\end{array}$ & Beta & T & Sig. & Tolerance & VIF \\
\hline (Constant) & .239 & .182 & & 1.312 & .192 & & \\
\hline $\begin{array}{l}\text { Competency } \\
\text { of IA }\end{array}$ & .160 & .101 & .146 & 1.584 & .116 & .526 & 1.901 \\
\hline $\begin{array}{l}\text { Independence } \\
\text { of IA }\end{array}$ & .136 & .088 & .125 & 1.557 & .122 & .686 & 1.458 \\
\hline $\begin{array}{l}\text { Work } \\
\text { Quality of IA }\end{array}$ & .117 & .116 & .096 & 1.009 & .315 & .488 & 2.050 \\
\hline $\begin{array}{l}\text { Management } \\
\text { Support }\end{array}$ & .416 & .089 & .392 & 4.670 & .000 & .632 & 1.583 \\
\hline
\end{tabular}

a:Dependent Variable: Effectiveness of IA

Source: Field Survey 2020

\section{Competence of the Internal Audit Team}

This segment addresses participants' opinions on the competence of the IA staff as a variable that might impact IA efficiency. In this respect, the investigator studied the competence of IA from the perspective of competence, efficient communication, experience, training and development and access to IT.

$\mathrm{H}_{1}$ : Competence of the IA team is positively related to the efficacy of IA in ACBs.

The first hypothesis analyzed the IA team's competence in a positive association with IA's success in ACBs. The figure shows IA team competence weak linkages to IA effectiveness in ACBs at a statistical importance mark of $(\mathrm{P}<0.05)$. The magnitude $(\beta)$, which influenced IA effectiveness, was 0.160 and the T-value was 1.584 respectively. The sign of a positive scale and a t-value of less than 2 imply that the independent and dependent variables are not strongly linked Hair, et al., (1998). Adequate awareness requires a minimum first-grade standard, qualified membership, and 
qualification in specific fields, such as CIA ${ }^{15}$ Mihret (2008); Abu-Azza (2012); IIA (2018). Communication theory suggests that inappropriate information or communication complexity can lead to an inability to communicate effectively Hanefah and Endaya (2013). A small and large amount of information is not sufficient for effective communication.

The researcher, therefore, rejects the hypothesis that the competence of the IA team is positively linked to the efficacy of IA in ACBs. The result has shown that the capabilities of the IA teams do not play a significant role in the effectiveness of IA concerning their competence. This skill has not had a significant impact on IA efficiency in ACBs, as well as internal audit experience, effective communication with the auditees, training, and development, and access to IT. The result is not aligned with the previous research Misganaw (2016) but matched with Cohen and Sayag (2010).

\section{Independence of the Internal Audit Team}

The core issue for IA productivity is independence because, without IAD autonomy, IA output cannot be attained Cohen and Sayag (2010); Santagato, L. \& Vanasco, R. Skousen (1996). This section assesses participants' views on IA freedom as a feature that can affect the efficiency of the IA. The study tested, in this regard, the liberation of IA from the presence of an efficient $\mathrm{AC}$, the independence of individual in-house auditors and organizational independence from the perspective of IA function.

$\mathrm{H}_{2}$ : Independence of IA is positively linked with the efficacy of IA in ACBs.

The second hypothesis tested IA's positive correlation independence with IA's efficacy in ACBs. The result shows the IA independence at a statistical significance level of $(\mathrm{P}<0.05)$ had not significantly connected with the efficiency of IA in ACBs. The magnitude $(\beta)$ of this variable's effect on IA's efficacy was 0.136 and the $t$-value of 1.557 . The positive sign of magnitude and t-value of less than 2 shows a weak interaction between DV and IVs. Hair, et al., (1998). Thus, the researcher does not support the study's hypothesis that IA independence is positively correlated with IA efficacy in ACBs. The result shows that IA independence performs a less influential position in the

${ }^{8}$ Certified Internal Auditors 
effectiveness of IA in ACBs. This means that the existence of an active AC; the individual IA liberation and the organizational independence of IA have had an insignificant effect on the efficacy of IA in the ACBs. The finding doesn't conform to previous studies Subramaniam, (2010); George (2015); Goodwin-Stewart (2001).

\section{Quality of the Internal Audit Team}

The quality of IA can be demonstrated through the office of internal auditors and the capacity of fieldwork to fulfill their obligation to provide valuable findings and feedback Mihret and Yismaw (2007). This research examined audit quality from the viewpoint of efficient audit planning and monitoring Prawit, et al. (2010), IA fieldwork, finding and reporting follow-up on IA advice, and good communication with external auditors.

$\mathrm{H}_{3}$ : Quality of IA work is positively associated with the effectiveness of IA in ACBs.

The investigator rejects the third hypothesis evaluating IA's quality of work positively linked with IA's success in ACBs. The paper shows a weak association at a statistical significance level of $(\mathrm{P}<0.05)$ between the quality of IA work and efficacy of IA in ACBs. The magnitude $(\beta)$ of this variable's effect on IA's effectiveness was 0.117 , and the t-value was 1.009 . The positive sign of magnitude with a t-value of less than 2 suggests a poor interaction between IV and DV Hair, et al., (1998).

The finding shows that the quality of IA work in ACBs has not had a significant effect on IA efficiency. That means efficient audit scheduling and supervision; IA exploration; recording analysis, and recommendations; the purse of IA recommendations; and effective communication with outdoor inspectors have had an insignificant influence on the efficacy of IA in ACBs. The finding is consistent with earlier studies Ramachandran, et al., (2012); Abu-Azza (2012), but differs with Wubishet and Dereje (2014); Mihret and Yismaw (2007). 


\section{Management Support}

Management support is the factor in determining the effectiveness of IA Mihret and Woldeyohannis (2008); Ababa (2016); Mihret and Yismaw (2007). Because IA activities are carried out in a dynamic and supportive environment; the internal auditors expect the top management to support them. Organizational autonomy to successfully do their jobs; according to SPPIA interior assessors should be assisted by top management, BOD IIA (2017). Top management support is therefore needed to enhance efficient work performance. The researcher focused on senior management assistance.

$\mathrm{H}_{4}$ : Management supports are positively linked with the effectiveness of IA in ACBs.

Finally, the last hypothesis evaluated management supports which shows a positive association with the success of IA in ACBs. The result shows that management supports strongly correlated with the efficacy of IA in the ACBs at a statistically significant point $(\mathrm{P}<0.05)$. The magnitude $(\beta)$ of this variable's effect on IA's effectiveness was 0.416 , and the t-value was 4.670. The positive sign of magnitude and $t$-value greater than 2 proposes a strong relation between IV and DV Hair, et al., (1998).

Abu-Azza (2012) explains management support as a motivation given to internal auditors by the top management. Financial support may be reflected in providing the IAD with an appropriate budget and providing financial benefits (remuneration and bonuses) to IA teams Abu-Azza (2012). The nature and standard of audit research are greatly influenced by the adequate budget.

Therefore, the investigator confirms the results of the study hypothesis that supports from management are positively correlated with IA effectiveness in ACBs. The result shows that supports from management play a critical role in IA's effectiveness. This means that top management knowledge of IA's requirements and helps across financial and non-financial assistance has an important impact on IA's effectiveness in ACBs. The observation is aligned with earlier research. Cohen and Sayag (2010); Gortiz (2004); Stocks, Schueler, and Albercht, (1988); George (2015); Mihret and Yismaw (2007); Paape (2007). 


\section{CONCLUSION AND RECOMMENDATION}

\section{Conclusion of the Study}

IA has a crucial role to play in assisting a firm reaches its goals while it is successfully managed, executed, and functioned. Organizations that coped, implemented, and operated IA efficiently were better able to recognize their organizational threats and system inefficiencies to take corrective actions and improve the process. The following relevant results are listed based on the survey.

The IA personnel's competence, independence, and quality in the efficacy of IA in ACBs do not play a vital role. The reliability of the IA in ACBs has not been significantly affected by the competence and the expertise of interior inspectors, efficient interaction with the auditors, education, training, and access to IT. The challenges and weaknesses of ACBs' IAD in this regard are not related to the above issues. There was no lack of sufficient certified individuals in ACBs relevant to the expertise of IA teams, there was no lack of good interaction skills with the head level and auditees neither lack of IA software for audit management activities in ACBs. Also, the strength can be described as the capacity of auditors to access the use of information technology and attract personnel with at least B.A degree and two years of practice in auditing, efficient interaction and support through branch-level assessments and a positive commitment to external training and development. In conclusion, the IA team competency at a statistical significance point of $(\mathrm{P}<0.05)$ is not positively associated with the efficacy of IA in ACBs.

In the efficiency of IA for ACBs, the independence of IA has not got any critical role. This means that there were no major impacts on IA's effectiveness in ACBs due to the presence of an efficient audit committee, individual IA, independence, and organizational independence. To conclude, IA independence is not linked positively with the efficacy of IA in $\mathrm{ACBs}$ at a statistically significant $(\mathrm{P}<0.05)$ level.

The IA quality functions had no significant influence on the performance of IA in ACBs. The effectiveness of IA in ACBs is not affected by effective audit scheduling and observation; IA information-gathering; recording, 
results, and recommendations; follow-up on IA recommendations; and efficient interface with exterior assessors. To conclude, the quality of the IA function shows a poor correlation between the output of IA quality and the success of IA in ACBs at a statistically significant point $(\mathrm{P}<0.05)$.

By comparison to the independence, competence, and quality of the IA teams; management commitment and supports play a critical role. This indicates a significant effect on IA efficiency in ACBs through senior management awareness on IA needs and support through financial and nonfinancial objects. The concern with management support linked to ACBs was a smaller sum fund given to the IA team as rewards and incentives. In conclusion, management supports strongly affect the effectiveness of IA in ACBs at a statistical significance point of $(\mathrm{P}<0.05)$. Management supports have therefore significant and statistically relevant effects on the efficacy of IA in value-adding role, improving department performance, and improving organizational performance. So, the factor which affected the IA in ACBs was management support. Whereas IA independence, IA competence, and IA quality have not significantly affected IA efficiency. It implies that IA independence, IA team competence, and quality of IA are not determinants of IA's efficiency in ACBs.

\section{Recommendation of the Study}

The ultimate intention of the research is to recognize IA efficacy factors in ACBs. In this respect, quantitative data analysis was performed. The investigator provides the following recommendations to the relevant parties, based on the research objective and the data analysis.

- Senior management should support IAD's staff through nonmonetary and monetary incentives.

- To effectively carry out the daily works, top management authorities should expand the IAD.

- Needs and requirements of in-house inspection team should be positively responded, by the senior management authorities. 
Sarens, G. and Debeelde, I. (2006) from the other side, consider that the firm's complete recognition and appreciation of IA rely heavily upon the consideration of the top management.

Eventually Abu-Musa (2008) clarified management support as an encouragement for top management to provide internal auditors. Therefore, adequate IAD allocation, IA Project incentives, rewards, and IA feedback are recognized and adopted. Financial support for an appropriate budget allocation for the IAD and competitive opportunities for the IA team should be presented.

\section{Suggestion for further studies}

The investigator inspires more studies to maximize and improve the outcomes of the research by reducing the study's restriction. The investigator, therefore, propose the following potential areas of research:

- Research will be validated through analysis in different sectors and countries.

- This research will be further suggested by replicating the analysis regarding the members of the BODs, the Administrative Operations Department, Financial Managers, and the Organizations' CEO reliance.

\section{REFERENCES}

[1]Abu-Azza, W. O. (2012). Perceived Effectiveness of the Internal Audit Function in Libya:AQualitative study using Institutional and Marxist Theories. Australia: School of Accounting, Economics and Finance; Faculty of Business Law.

[2]Abu-Musa, A. (2008). Information Technology and its Implications for Internal Auditing: An Empirical Study of Saudi Organization. Managerial Auditing Journal, 23(5), 437-467.

[3]Adams, M. (1994). Agency Theory and the Internal Audit. Management Auditing Journal, 9(8),7-14. 
[4]Arens, A. A. (2012). Auditing and Assurance Services: an Integrated Approach. (14th, Dü.) New Jersey: Pearson Prentice Hall.

[5]Basel (2012). The Internal Audit Function in Banks. Bank for International Settlements Press \& Communications. Switzerland: Basel Committee on Banking Supervision.

[6]Belay, Z. (2007). Effective Implementation of Internal Audit Function to Promote Good Governance in the Public Sector. Addis Ababa, Ethiopian Civil Service College Research, Publication \& Consultancy Coordination Office.

[7]Boone Jr, H. N. \& Boone, D. A., (2012). Analyzing Likert Data. Journal of Extension, 50(2), pp. 1-7.

[8]Brooks, C., (2008). Introductory Econometrics for Finance. 2nd ed. Cambridge: Cambridge University Press.

[9]Changwony, M. K. \& Rotich, D. G. (2015). Role of Internal Audit Function in Promoting Effective Corporate Governance of Commercial Banks in Kenya. International Journal of Business \& Law Research, 3(1), 14-34.

[10]Cohen, A. \& Sayag, G. (2010). The Effectiveness of Internal Auditing: An Empirical Examination of its Determinants in Israeli Organizations. Australian Accounting Review, 30(54), 295-308.

[11]Cooper, D. R. \& Schindler, P. S., (2006). Business Research Methods. 9th Ed. New York: Mc Graw-Hill/Irwin.

[12]Creswell, J. W., (2003). A framework for Design. In: C. D. Laughton, V. Novak, D. E. Axelsen \& \&. A. J. Sobczak, eds. Research Design: Qualitative, Quantitative, and Mixed Methods Approaches. California, USA: Sage Publications, Inc., pp. 1-27.

[13]Creswell, J. W., (2009). Research Design: Qualitative, Quantitative, and Mixed Methods Approach. 3rd ed. California: Sage Publications Inc.

[14]Cronbach, J. L., (1951). Coefficient Alpha And The Internal Structure Of Tests, Psychometrika, Vol. 16, No. 3, September.

[15]Da Afghanistan Bank. (2020). DAB History. Da Afghanistan Bank: https://dab.gov.af adresinden alınd1 
[16]Fadzil, F. H., Haron, H. \& Jantan, M. (2005). Internal auditing practices and internal control system. Managerial Auditing Journal, 20(8), 843-867. [17]Gamage, C., Lock, K. L. \& Fernando, A. . (2014). A Proposed Research Framework: Effectiveness of Internal Control System in State Commercial Banks in Sri Lanka (Cilt 1). International Journal of Scientific Research and Innovative Technology.

[18]George, D., Theofanis, K. \& Konstantinos, A., (2015). Factors associated with Internal Audit Effectivness: Evidence from Greece. Journal of Accounting and Taxation, 7(7), pp. 112-123.

[19]Gilchrist, D. Pilcher, R. \& Singh, I. (2011). The Relationship Between Internal and External Audit in the Public Sector: A Case Study. s.l. AFAANZ Conference.

[20]Gortiz, A. (2004). The impact of material incentives on response quantity, response quality, sample composition, survey outcome and cost in online access panels. International Journal of Market Research, 46(4), 325-347.

[21]Goodwin-Stewart, J., (2001). Two Factors Affecting Internal Audit Independence and Objectivity: Evidence from Singapore'. International Journal of Auditing, Volume 5, pp. 105-127.

[22]Hair, J., Anderson, R., Tatham, R. \& Black, W., (1998). Multivariate Data Analysis. 5th ed. New Jersey: Pearson Prentice Hall.

[23]Hanefah, M. M. \& Endaya, K. A. (2013). Internal Audit Effectiveness: An Approach Proposition to Develop the Theoretical Framework (Cilt 10). (4, Dü.) Research Journal of Finance and Accounting.

[24]Ibrahim M. S., Shokiyah, A. \& Baharud-din, Z. (2014). Factors that contribute to the effectiveness of internal audit in Public sector. IPEDR, 70(24), 125-133.

[25]IIA. (2017). Standards for the Professional Practice of Internal Auditing. Florida: Altamonte Springs.

[26]IIA. (2018). IPPF-Practice Guide: Measuring Internal Audit Effectiveness and Efficiency. Florida: Altamonte Springs. 
[27]Keatinge, T. (2014). The Role of Public and Private Sector Banking in Ethiopia's Future Economic Growth. Goshen: Global Center on Cooperative Security.

[28]Kothari, C., (2004). Research Methodology Methods and Techniques. 2nd Revised Edition Ed. New Delhi: New Age International Limited Publisher.

[29]Marczyk, G., DeMatteo, D. \& Festinger, D., (2005). Essentials of Research Design and Methodology. Hoboken, New Jersey: John Wiley \& Sons. Inc.

[30]Mihret, D.G. \& Woldeyohannis, G.Z., (2008). Value-added role of internal audit: an Ethiopian case study. Managerial Auditing Journal, 23(6), pp. 566-596.

[31]Mihret, D.G. \& Yismaw, A.W., (2007). Internal Audit Effectiveness: An Ethiopian Public Sector Case Study. Managerial Auditing Journal, 22(5), pp. 469-485.

[32]Misganaw, T. (2016), Factors Determining Effectiveness of Internal Audit in Ethiopian Commercial Banks. Addis Ababa, Ethiopia: Addis Ababa University.

[33]Moeller, R. R. (2004). Sarbanes-Oxley and New Internal Auditing Rules (1st b.). New Jersey: John Willey \& Sons, Inc.

[34]Nagy, A. \& Cenker, W. (2002). An assessment of a newly defined internal audit functions. Managerial Auditing Journal, 17(3), 129-138.

[35]Paape, L. (2007). Corporate Governance: The Impact on the Role, Position, and Scope of Services of the Internal Audit Function. Erasmus University.

[36]Prawit, D., Smith, J. \& Wood, D. (2010). Internal Audit Function Quality and Earnings Management (4 b., Cilt 84). The Accounting Review.

[37]Ramachandran, D. J., Subramanian, D. R. \& Kisoka, \&. I. J., (2012). Effectiveness of Internal Audit in Tanzanian Commercial Banks. British Journal of Arts and Social Sciences, 8(1), pp. 31- 45. 
[38]Reisinger, H., (1997). The Impact of Research Designs on R2 in Linear Regression Models: an Exploratory Meta-Analysis. Journal of Empirical Generlaizations in Marketing Science, 2(1), pp. 1-12.

[39]Santagato, L. \& Vanasco, R. Skousen, C. . (1996). Auditor Independence: An International Perspective. Managerial Auditing Journal, 11(9), 2-50.

[40]Sarens, G. \& Debeelde, I. (2006). The Relationship between Internal Audit and Senior Management: A Qualitative Analysis of Expectations and Perceptions. International Journal f Auditing, 10(3), 217-242.

[41]Saunders, M., Lewis, P. \& Thornhill, A., (2009). Research Methods for Business Students. 5th ed. Harlow, England: Pearson Education Limited.

[42]Shewhart, W. A. \& Wilks, S. S., (2004). Methods for Testing and Evaluating Survey Questionnaires. In: R. M. Groves, et al. eds. Wiley Series in Survey Methodology. New Jersey: A John Wiley \& Sons, Inc. Publications.

[43]Staciokas, R. \& Rupsys, R. (2005). Internal Audit and its Role in Organizational Government. Internal Audit and its Role in Organizational Government. adresinden alındı

[44]Stocks, K., Schueler, D. \& Albercht, W., Howe, K. (1988). Evaluating the Effectiveness of Internal Audit Departments. Florida: The Institute of Internal Auditors Research Foundation Altamonte Springs.

[45]Subramaniam, N. \& Stewart, J. (2010). Internal Audit Independence and Objectivity: Emerging Research Opportunities. Managerial Auditing Journal, 25(4), 328-360.

[46]Tandon, B., Sudharsanam, S. \& Sundharabahu, S. (2010). A Handbook of Practical Auditing. New Delhi: S. Chand \& Company Ltd.

[47]Thompson, B., (2002). "Statistical", "Practical", and "Clinical": How Many Kinds of Significance Do Counselors Need to Consider? Journal of Counseling and Development, Vol. 80, pp. 64-71.

[48]Vanek, C. (2012), Likert scale-What is it? When to use it? How to analyze it? s. 1.: Survey Gizmo.

[49]Willborn, W. \& Karapetrovic, S. (2000). Quality Assurance and Effectiveness of Audit Systems. International Journal of Quality and Reliability Management, 17(6), 680-704. 
[50]William, D. G., Brierley, J. A. \& Al-Twaijry, A. (2003). The development of internal audit in Saudi Arabia: an institutional theory perspective. Critical Perspectives on Accounting, (Cilt 14).

[51]Wubishet, J. D. \& Dereje, G. R. (2014). Factors Determining Internal Audit Quality: Empirical Evidence from Ethiopian Commercial Banks. Research Journal of Finance and Accounting, 5(23), 86-95.

[52]Xiangdong, W. (1997). Development of trends and future prospects of internal auditing. Managerial Auditing Journal, 12(4), 199-205.

[53]Yin, R., (2003). Case Study Research: Design and Methods. 3rd ed. Thousand Oaks: Sage Publications. 